\title{
Between medicine and rhetoric: therapeutic arguments in Roman Stoicism
}

\author{
Krzysztof ŁAPIŃSKI*
}

\begin{abstract}
In this paper, I intend to focus on some rhetorical strategies of argumentation which play crucial role in the therapeutic discourse of Roman Stoicism, namely in Musonius Rufus, Epictetus, Seneca, and Marcus Aurelius. Reference is made to Chaim Perelman's view of ancient rhetoric as an art of inventing arguments. Moreover, it is pointed out that in rhetorical education (cf. Cicero, Ad Herennium, Quintilian, etc.) as well as in therapeutic discourse the concept of "exercise" and constant practice play a crucial role.
\end{abstract}

\section{KEYWORDS}

Stoicism; Musonius Rufus; Epictetus; Seneca; Marcus Aurelius; Chaim Perelman; consolation; spiritual exercise

* PhD, assistant professor, Institute of Philosophy, University of Warsaw. E-mail: k.lapinski@uw.edu.pl. This research paper was supported by an NCN Miniatura 2 grant to carry out research at the University of Cambridge, UK (reg. no. 2018/02/X/HS1/01200). 
Ancient Greek and Roman philosophy was focused not only on inquiring into the nature of the world, but also on transforming human minds. In order to describe that tendency more adequately, various scholars have labelled it as, for example, spiritual exercises (Pierre Hadot), the art of living (Michel Foucault), the therapy of desire (Martha Nussbaum), or spiritual guidance (Paul Rabbow and Ilsetraut Hadot). The therapeutic paradigm becomes predominant in Hellenistic and Roman times. Epicurus reduces philosophy to the fourfold cure (tetrapharmakos); Lucretius declares that his poem is like sour drugs, but the poetical form is like honey which makes the drugs sweeter. For Sextus Empiricus, a sceptical argumentation is a sort of mental laxative. Chrysippus stresses that there is an art concerned with the diseased soul, corresponding to medicine, and Epictetus compares a school where philosophy classes take place to an iatreion, a hospital. Other Stoics, like Musonius Rufus, Seneca, or Marcus Aurelius, use medical analogies extensively. This idea survived until the very end of antiquity, when Boethius composes his Consolation of philosophy, and Simplicius comments on Epictetus' Enchiridion. In this paper, I will focus on the references made by Musonius Rufus, Epictetus, Seneca and Marcus Aurelius to medical analogy and rhetoric. I intend to show how some notions and metaphors borrowed from medicine and rhetoric are manifested in the therapeutic discourse of the Roman Stoics. I want to present it by referring to the examples of various literary forms of this discourse, such as diatribe, dialogue, and soliloquy.

\section{INTRODUCTORY REMARKS: PLATO AND ARISTOTLE}

Greek philosophy extensively used the achievements of other disciplines, among which were medicine and rhetoric. The paideutic ambitions of philosophy are clearly visible at least from Socrates' times onwards, partially as his polemical response to the Sophists' engagement in education in the Greek poleis. Socrates' mission, which consisted in caring for the souls of his citizens, was to decisively shape ancient philosophy. Medicine becomes a regular point of reference for philosophers who discussed ethical problems. The medical analogy, which relies on comparing the health, sickness, and therapy of the body to those of the soul, was useful in juxtaposing the medical point of view with the ethical one. In his Gorgias and Republic, Plato equates justice in the soul with its healthy condition, and moral corruption with its sickness. This way of thinking prevailed in philosophy until the end of antiquity. On the other hand, from Plato onwards, rhetoric had a bad press, which was especially connected to the political role which the Sophists played in ancient Greece. However, even Plato, who attacks orators and sophists most vehemently, in his Phaedrus (270c) makes a proposal to create a philosophical rhetoric which could take 
Hippocratic medicine as its model. This kind of rhetoric would be a useful tool for a teacher to convince young students of what is good from the perspective of philosophical paideia. The relationship between philosophy and rhetoric was complex and ambiguous, and cannot be reduced to the simple formula of a "quarrel" between both disciplines (Kasulke, 2005). First and foremost, education in ancient Greece as well as in Rome often consisted of two pillars: rhetoric and philosophy. Some ancient authors explicitly stated that they drew inspiration from both disciplines. This is especially evident in Roman writers, e.g., in Cicero (De oratore 3) and Quintilian (Institutio oratoria $1.13 \mathrm{ff}$.), who declare that they want to reconcile both arts. They underline that an orator has to know philosophy, and a philosopher should be well acquainted with the art of speaking.

Aristotle, who explored the relationship between rhetoric and philosophy systematically, pays attention to rhetoric as the art that deals with a particular way of reasoning. ${ }^{1}$ His detailed analyses go far beyond Gorgias' exultation at the power of peitho or Plato's general remarks about the influences of rhetoric on education and political life. Aristotle justifies the need for interest and competence in rhetoric, claiming that the awareness of rhetorical devices and their functioning is indispensable, if someone wants to defend themselves against rhetoricians' deceits (Aristotle, Rhetoric 1355a). For Aristotle, rhetoric is mostly the art of inventing and applying persuasive arguments in a situation when premises are vague, arbitrary or not explicitly expressed (enthumemata). Rhetoric deals with values which are the result of consensus within a given community, but at the same time that consensus can be changed if some different aspects of the problem discussed are emphasized. In other words, rhetoric begins where strict scientific knowledge ends. ${ }^{2}$ Aristotle makes rhetoric a productive, or "poietic", art, because it aims at producing persuasion, just like medicine, which is "poietic" as well, aims at producing health. The argumentation which can be identified in rhetoric differs from the strictly theoretical approach that is to be found in, for example, "first philosophy". In his Metaphysics, Aristotle emphasizes that research into "first philosophy" is "useless" (Aristotle, Metaphysics 982b), which means that it has no external, utilitarian goal. On the other hand, rhetorical persuasion is goal-oriented, and the same inclination is to be found in the therapeutic argumentation in philosophy. It might be said that like medicine, which "produces" health, and

1 This way of thinking about rhetoric, as the art of a particular kind of argumentation, returns in Chaim Perelman's "new rhetoric", cf. Perelman, 1982. For Aristotle's role in the history of rhetoric, cf.: "In fact Aristotle deserves the credit for connecting rhetoric with dialectic and poetry, without losing sight of its practical employment in the assembly and courts of law" (Calboli, 1990: 47).

${ }^{2}$ In the case of rhetoric and its object, Aristotle could repeat what he had said about the impossibility of precision in his own research in ethics (Aristotle, Nicomachean ethics 1094b). 
rhetoric, which "produces" persuasion, therapeutic argumentation in philosophy aims at "producing" health in the souls of students through persuading them to eradicate their vices. In contrast to the pure theoretical approach, therapeutic arguments have to be effective, like medical treatment and rhetorical persuasion. A philosophy teacher who takes care of the souls of his students must select arguments which are best suited to a given situation. The teacher uses such therapeutic argumentation for the sake of its effect, i.e., the health of the students' souls. Stoic thinkers of the Imperial Period were particularly interested in that type of discourse. The therapeutic paradigm was so important for them that they did not hesitate to adapt useful therapeutic topics from other philosophical schools. ${ }^{3}$ They often became eclectic for the sake of therapeutic efficiency.

\section{MEDICAL ANALOGY IN STOICISM}

Medical analogy is ubiquitous in Stoic writings. It can be found in Zeno of Citium and Chrysippus, as well as in the Stoics of the Imperial Period, namely in Musonius Rufus, Epictetus, Seneca, and Marcus Aurelius. In his On passions, Chrysippus builds an analogy between medicine and philosophy, which are two technai that care respectively for the body and the soul (Tieleman, 2003: 145 ff.; Annas, 2000: 109 ff.). Musonius claims that the task of a philosopher is more difficult than that of a doctor, as the diseases of the soul are more demanding than those of the body. Epictetus compares the philosopher's classroom to a hospital (Epictetus, Discourses 3.23.30). Seneca very often refers to the medical analogy, stressing that if people want to be sound, they must practice philosophy. It means that the mind (animus) must be exercised day and night (Seneca, Epistulae 15.5). In Epistle 120, he asks: how did human beings acquire knowledge of what is good and what is honourable (bonestum)? The answer is that the good and the honourable have been comprehended by analogy. Seneca explains it: "We understood what bodily health was: and from this basis we deduced the existence of a certain mental health also" (Seneca, Epistulae 120.5). ${ }^{4}$ It is quite possible that Seneca follows Chrysippus, who presents similar reflections upon analogy in his On passions. According to Chrysippus, the medical analogy emerged naturally in human language and minds, arising from human tendency to analogical reasoning: "For we do in fact say that some persons are strong or weak also in respect of their soul, and firm or

${ }^{3}$ In Epicureanism also the theoretical part of philosophy is subordinated to the practical one. In his Letter to Pythocles (85), Epicurus writes: "First of all, do not believe that there is any other goal to be achieved by the knowledge of meteorological phenomena [...] than freedom from disturbance and a secure conviction" (Epicurus, 1994: 19).

${ }^{4}$ Trans. by R.M. Gummere (Seneca, 1925). 
soft, and moreover ill or healthy; and we speak in this way of emotion, infirmity and the like in the soul". ${ }^{5}$

\section{PERSUASIVE LECTURING: MUSONIUS AND EPICTETUS}

Medical analogy shapes Stoic philosophical discourse in many ways. Musonius Rufus claims that teachers of philosophy must limit their arguments to those which are necessary and effective, like good doctors who prescribe only those medicines that are indispensable: "Thus just as the physician who prescribes many drugs for his patients deserves less praise than the one who succeeds in helping them only with a few, so the philosopher who teaches his pupils with the use of many proofs is less effective than the one who leads them to the desired goal with few" (Diatribes 1$)^{6}$. Not the quantity but the quality of arguments is essential. Musonius pays attention to the close relationship between a teacher and his students. They build a community of friends in which a philosopher teaches not only with his words but with his deeds as well. It is worth mentioning that in ancient rhetoric the way of life (ethos) of an orator is treated as the most important testimony of the credibility of his words (Aristotle, Rhetoric 1356a).

Epictetus recorded that Musonius practiced parrbesia, or truth-telling, inspired by the Cynic manner of speaking. He used to speak in this way to reprimand his students, telling them openly about their vices: "Wherefore he spoke in such a way that each of us as we sat there fancied someone had gone to Rufus and told him of our faults; so effective was his grasp of what men actually do, so vividly did he set before each man's eyes his particular weaknesses" (Epictetus, Discourses 3.29). ${ }^{7}$ As a teacher of philosophy, Musonius combined Stoicism, Cynic asceticism, and Socratic cross-examination.

According to Musonius, a philosopher's speech, which aims at helping students, must meet a few crucial requirements (Diatribes 1). Firstly, an argument must be applied in the right moment (en kairo) in order to be as effective as possible. The term kairos was common to ancient medicine as well as to rhetoric. Doctors, referring to their knowledge and experience, must know which medicines have to be applied in the given circumstances. Similarly, orators must select arguments best suited to their audience. Secondly, an argument must be precise (bikanos), and, thirdly, it must be persuasive (peistikos). These three requirements mean that the predominant element in argumentation is its effect, and more precisely, its therapeutic goal. It goes alongside Musonius'

5 Trans. by T. Tieleman (Tieleman, 2003: 145).

6 Trans. by C. Lutz (Lutz, 1947: 33).

7 Trans. by W.A. Oldfather (Epictetus, 1925-1928; all subsequent translations from Epictetus are by Oldfather). 
emphasis on the importance of askesis, or exercise in human life. Musonius introduces his own, twofold concept of askesis, consisting in the training of the soul, and the training of the body and the soul (Musonius Rufus, Diatribes 6). Effective argumentation about what is to be chosen and what is to be avoided is crucial to the training of the soul.

Epictetus, like his teacher Musonius, condemns those students who do not apply philosophy to their lives, but study it as if it were pure speculation or intellectual play. He points out that philosophy demands more than to learn and explain Chrysippus' writings (Epictetus, Enchiridion 49; cf. Seneca, Epistles 108). As Epictetus underlines, no one should read philosophers as if they were poets, i.e. focusing on style, grammar, etc. There are two ways of reading books: the philosophical and philological. The former should be accompanied by transferring philosophical doctrine to practice; the latter requires only scrutiny in analysing texts. While speaking about philosophical education, Epictetus stresses that the whole process requires effort and time. Doctrine must be followed by training (askesis) and habituation (etbismos). Knowledge is like food that has to be slowly digested, or like a seed which should be planted and cultivated (Epictetus, Discourses 4.8.39; cf. Seneca, Epistles 38). Flavius Arrian, who wrote down Epictetus' lectures, explains that while writing he wanted to imitate Epictetus' language and manner of expression, especially his frankness of speech (parrhesia). In his introductory note to the Discourses, Arrian explains: "Epictetus [...] was clearly aiming at nothing else but to incite the minds of his hearers to the best things" (Epictetus, Discourses). ${ }^{8}$ Simplicius, in his commentary on Epictetus' Enchiridion, writes similarly: "The speeches are very effective and stirring. But someone who is not affected by these speeches could only be corrected by the courts of Hades" (Simplicius, Introduction 193). ${ }^{9}$ Epictetus uses the language and form of the Cynic diatribe: colloquial phrases, emotional message, admonition combined with exhortation, quasi-dialogues and exclamations which arrest the listener's attention ${ }^{10}$. The rhetorical form in the speeches is subordinated to its therapeutic purpose.

\section{SENECA'S INDIRECT DIALOGUE}

Another example of such a therapeutic procedure can be found in Seneca's Epistles and Dialogues, where he represents the same line of argumentation about erudition as Epictetus. According to Seneca, books should be limited and carefully selected like medicines, because nothing is as harmful for one's health

\footnotetext{
${ }^{8}$ Arrian's introductory letter (Epictetus, 1925-1928).

9 Trans. by Ch. Brittain \& T. Brennan (Simplicius, 2002).

${ }^{10}$ On the literary form of Epictetus' writings see e.g. Long, 2004; on Epictetus' ethics and its practical dimension see e.g. Xenakis, 1969; Stephens, 2007; Sellars, 2009.
} 
as changing one's medicines too often (Seneca, Epistles 2). Epistles to Lucilius represent a close relationship between the teacher and his student. The written text enables them to cross the temporal and spatial distance. As Ilsetraut Hadot ascertains, Seneca plays the role of a spiritual guide for Lucilius, he uses protreptic and consolatory advice, or recommends to his pupil various spiritual exercises (Hadot, 1969). However, both sides find benefit in this relationship. Seneca shares the results of his philosophical progress with Lucilius, claiming that reciprocity is important for a teacher (Seneca, Epistles 6). But there is a kind of paradox in this spiritual guidance, because Seneca stresses that a written text is the second best medium of philosophical teaching in comparison to the spoken word of a teacher. Then he goes somewhat further claiming that what matters in philosophy are deeds, not words (Seneca, Epistles 6). Nevertheless, although philosophy cannot be reduced to mere words, the well-ordered words of a philosopher introduce order to the mind of his student (Seneca, Epistles 40). The term "order" (dispositio) was borrowed by Seneca from the rhetorical inventory, where it signifies the structure of a speech, thus assuming a sort of correspondence between words, thinking and action. As Seneca stresses: "talis hominibus oratio qualis vita" (Seneca, Epistles 114) ${ }^{11}$.

Rhetorical influences are clearly visible in Seneca's writings every time he uses the literary genre of consolation. At the beginning of the consolation to his mother Helvia, he explicitly compares the consolatory kind of argumentation to a medical procedure, and then he provides three main consolatory commonplaces, which populate other ancient texts belonging to this genre. In this way, medical analogy is followed by its rhetorical application. Similar topics are discussed concisely by Cicero in his Tusculan disputations 3.32, but in Seneca's dialogues, letters and Naturales questiones, we can see them woven into philosophical texts. These three topics are: redefinition, comparison, one's own attitude.

Starting his consolatory argumentation in the Consolation to Helvia, Seneca first attempts to redefine his own status as an exile in order to show it as indifferent. Seneca redefines his own exile as a mere "change" of the place, arguing that his true homeland, which is the cosmopolis, can be found everywhere. This is similar to the argumentative strategy which can be found in Marcus Aurelius' Meditations, where he discusses the problem of death and other similar topics. Marcus finds a solution in a similar technique, namely in making analyses of various allegedly good or bad things which seem to be pleasurable or fearful respectively. He tries to reduce these things to their most fundamental features to show they only pretend to be good or bad, pleasurable or fearful, and if so, they are not worth desiring or avoiding. Consequently, luxury food or wine turns out to be the corpse of a fish or the mere juice of grapes (Marcus

${ }^{11}$ On the topos of talis oratio qualis vita, cf. Möller, 2004. 
Aurelius, Meditations 6.13), and death happens to be nothing but a change, which makes it just one of the natural phenomena. But Marcus goes even further. Given that nature is providential, every process which belongs to nature serves some good. The conclusion is that death as a change has its place in the whole providential order of the universe and is beneficial for it, being its indispensable part. This procedure of redefining is called a physical definition by Pierre Hadot (Hadot, 1998: 104 ff.). However, not only natural phenomena can be defined in this way, but also such things as exile, political institutions, social roles and so on. It might be said that the strategy of argumentation consists in selection, namely in refocusing on the positive aspects of the whole complex situation to bring them out and to put them before someone's eyes, which results in ignoring all the rest which are negative. It might be argued that in some sense death is change, but in another the word "change" does not exhaust the complexity of this phenomenon and human perception of it, and there are plenty of other elements involved in death and dying which are omitted in this kind of discourse. However, therapeutic discourse requires this definition to be accepted, which fulfils the therapeutic aim. Epictetus goes further, from indifference to gratitude, encouraging people to feel gratitude even in the face of the death of their closest relatives, like someone's own children. He recommends not focusing on death but on the time before it, and to think about the relationships themselves, seeing them as a gift (Epictetus, Enchiridion 11).

In Seneca's Consolation to Helvia, the redefinition of the exile is followed by the topic of comparison. Thus, the next argumentative step in Seneca's consolation consists in comparing his own condition to the conditions of other people who suffer even worse, and experience more desperate circumstances. This allows him to "calibrate" his expectations and see his own particular condition as a universal experience shared by all humankind. It appears that it would be equally possible to provide examples for, as well as against, the claim that a lot of people experience some kind of exile, but the therapeutic aim is predominant here as well. Moreover, both of the above-mentioned arguments seem to be contradictory, as the first aims at demonstrating that such a condition as exile is not exile at all. On the other hand, the second aims at proving that people who travel, migrate, or change their location for any other reason are in some sense exiled.

Another topic in the Consolation points out that distress cannot provide any advantage in a difficult situation. This argument refers implicitly to the Stoic division into the things in someone's control and the things out of someone's control, something very often discussed by Epictetus. The persuasive force of this argument is based, as it were, on a sort of economy of emotions: negative emotions cannot change external circumstances into ones more favourable, they can only influence someone's internal experiencing of these circumstances making them much worse. 
It is worth noting that these three topics refer, respectively, to the world, to other people, and to oneself, covering all the possible relations a subject can be involved in. Although they are selective and sometimes based on arbitrary assumptions, nevertheless they fulfil their role as tools of therapeutic persuasion.

\section{MARCUS AURELIUS' SOLILOQUY}

The above-mentioned texts were intended to be published, but the case of Marcus Aurelius' Meditations was probably different, because it seems that the emperor was writing for his private use only (Brunt, 1974: 5). The work is composed of written exercises in the form of a soliloquy. In this inner dialogue the author attempts to persuade himself to take the Stoic attitude towards the world. The proper philosophical attitude should be characterized by alertness towards everything that is brought by fate, other people, and one's own emotions and judgements. The principles of philosophy should be repeated systematically. They must be ready at hand to be read, memorize, digested, and exercised every day from dawn to dusk (Sellars, 2009: $147 \mathrm{ff}$.). Marcus explains it using a medical metaphor: "As doctors have their instruments and scalpels always at hand to meet sudden demands for treatment, so do you have your doctrines ready in order to recognize the divine and the human" (Marcus Aurelius, Meditations 3.13). ${ }^{12}$ References to health are frequent in Meditations when Marcus writes about "healthy" or "sound" (bygies) language, conduct of life, and hegemonikon, e.g.: "Use words that ring true (bygies)" (Meditations 8.30, $8.47,11.9$ ). "It is my joy, if I keep my governing self-intact (ean bygies echo to begemonikon), not turning my back to any human being, nor on anything that befalls men, but seeing everything with kind eyes, welcoming and employing each occasion according to its merit" (Meditations 8.43).

There are many types of exercises that can be distinguished in Meditations, and it is worth mentioning at least a few of them. Exercise in defining; this kind of training enables Marcus to see things in their relations to himself, fate, etc.: "Always make a definition or outline of the imagined object as it occurs, in order to see distinctly what it is in its essence" (Meditations 3.11; with my minor change). Its variation is a physical analysis, which prevents giving any illusory value to things: "when you are seated before delicacies and choice food to impress upon your imagination that this is the dead body of a fish, the dead body of a bird or a pig; and again, that the Falernian wine is but grape juice" (Meditations 6.13). Another exercise can be called "perspective": "A spider is proud to trap a fly, a man when he snares a leveret" (Meditations 10.10; with my minor change). Its variation is the "view from above": "when

${ }^{12}$ Trans. by A.S.L. Farquharson (Marcus Aurelius, 1944). All subsequent translations are by Farquharson. 
discoursing about mankind, look upon earthly things below as if from some place above them" (Meditations 7.48). ${ }^{13}$ "Asia and Europe are corners in the Universe. Every sea, a drop in the Universe; Mount Athos, a clod of earth in the Universe. Every instant of time, a pin-prick of eternity" (Meditations 6.36). Acceptance of fate, or even gratitude, is a crucial element of another exercise: "If so be that the gods took counsel about me and what must happen to me, they took counsel for good; for it is not easy to conceive a god without purpose, and on what possible ground would they be likely to desire to do me harm?" (Meditations 6.44). Finally, an exercise in taking inspiration from other people can be singled out: "Whenever you desire to cheer yourself, think upon the merits of those who are alive with you - the energy of one, for instance, the modesty of another, the generosity of a third, and of another some other gift. For nothing is so cheering as the images of the virtues shining in the character of contemporaries - and meeting so far as possible in a group. Therefore, you should keep them ready to your hand" (Meditations 6.48) ${ }^{14}$.

It is interesting that these private notes are not devoid of poetical and rhetorical refinement, which can be seen in the formal aspects of style, as well as in the metaphors and literary images. Using Heinrich Lausberg's terminology (Lausberg, 1998), there are figures of language and figures of thought in rhetorical theory. Both can be distinguished in Marcus, who uses rhetorical devices in his style of writing as well as in his argumentation. The former belong to the part of rhetoric called elocutio, the latter to inventio.

A famous rhetorician, Marcus Fronto, was one of the emperor's teachers whose pedagogical methods are well known from the surviving fragments of their correspondence (Marcus Aurelius et al., 1919; Pisini, 2012).${ }^{15}$ Fronto used to send Marcus various rhetorical and stylistic exercises for daily practice, and Marcus in response reported his progress to Fronto. ${ }^{16}$ Many ancient authors who taught rhetoric underline that the fundamental element of such an education is continuous training during the whole educational process. Even mature, professional orators must train in a daily manner if they want to stay sharp. There are plenty of passages in Cicero, Quintilian, Pliny the Younger, Rhetorica ad Herennium or handbooks containing so called progymnasmata, which confirm this need for constant training. It is interesting that parallel instructions can be found in philosophical texts representing the therapeutic paradigm. Epictetus recommends: "Have thoughts like these ready at hand (procheira) by night and by day; write them, read them" (Epictetus, Discourses 24). Marcus

\footnotetext{
${ }^{13}$ On the "view from above", see Rutherford, 1989: 155 ff.; Łapiński, 2018: $221 \mathrm{ff}$.

${ }^{14}$ For the detailed account of the types of spiritual exercises in Marcus Aurelius' Meditations cf. Hadot, 1998.

${ }^{15}$ For chronological controversies, see also Champlin, 1974.

16 "Altra regola da rispettare è l'esercizio quotidiano della scrittura [...], che diventa anche esercizio di pazienza, costanza, virtù” (Pisini, 2012: 135).
} 
Aurelius encourages himself to practice philosophy as soon as he wakes up (Meditations 2.1, 5.1, 8.12, 10.13).

There are many chapters in the Meditations which are rhythmical and symmetrically composed, with alliterations ${ }^{17}$ as well as with other figures that are typical of rhetorical prose, such as isocolon, ${ }^{18}$ homeoteleuton ${ }^{19}$ and so on. There are numerous other figures, that can be singled out: anadiplosis, ${ }^{20}$ epanadiplosis, ${ }^{21}$ polyptoton, ${ }^{22}$ epanaphora, ${ }^{23}$ and chiasmic composition. ${ }^{24}$ This rhetorical feature of the work, which can be classified as elocutio, may perform a self-persuasive function (Rutherford, 1989: 39-44, 126-155; Łapiński, 2018: 134-166). On the different level of the text we can find amplifications, similes, ${ }^{25}$ enumerations and literary commonplaces which enhance the persuasive effect of the utterances. Many of the topics reiterate as leitmotivs, because Marcus' work consists of exercises which are repeated in a systematic manner. Moreover, there are utterances with an iterative content (introduced by the iterative pronoun botan, "whenever, anytime"26) that refer to those returning situations for which the author has to be prepared by repeating his spiritual exercises. Marcus often uses exhortations or imperative sentences with action verbs such as: think, remember, do, etc., which is a stylistic feature directly inherited from Epictetus' Diatribes. The illocutive character of utterances used

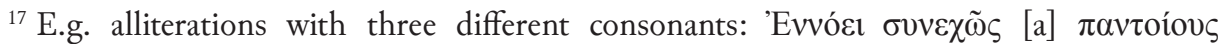

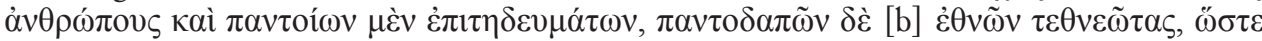

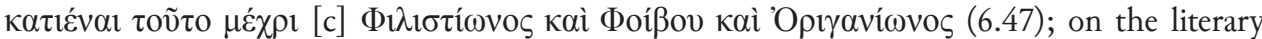
form and rhetorical figures in Marcus' Meditations cf. Dalfen, 1967; Giavatto, 2008; Rutherford, 1989; Łapiński, 2018: 134-167.

${ }^{18}$ For isocolon, or the figure in which parallel parts have the same number of syllables or

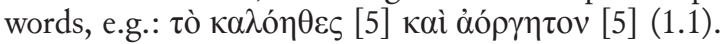

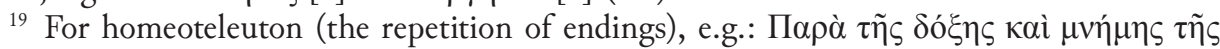

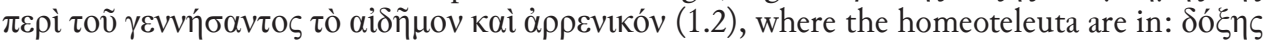

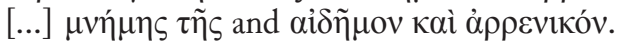

${ }_{20}$ For anadiplosis, or repetition of the last word of a previous sentence, cf.: $\tau$ òv $\alpha$ vò̀ $v$

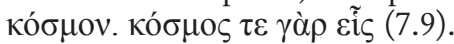

${ }^{21}$ Epanadiplosis, or the repetition of the beginning of a clause at the end of that same

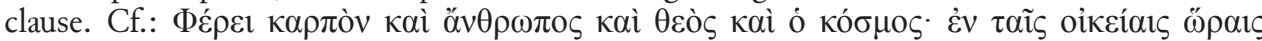

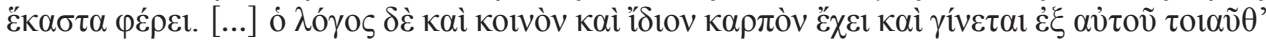

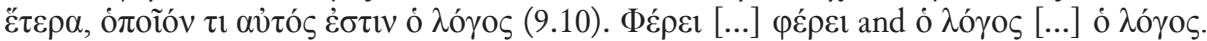

${ }_{22}$ For polyptoton, or a figure where relative words are repeated, e.g.: $\dot{\alpha} \lambda \lambda \dot{\eta} \lambda$ ors [...]

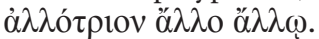

${ }^{23}$ For epanaphora, or repetition of a phrase at the beginning of following phrases,

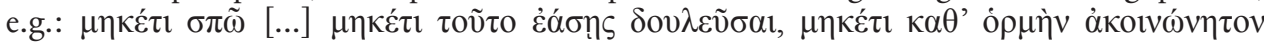

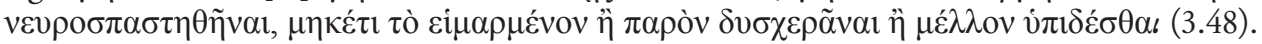

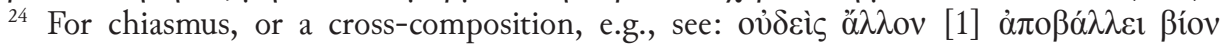

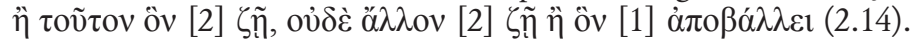

${ }_{25}$ More about comparison in the history of rhetoric, cf. McCormick, 2014.

${ }^{26}$ E.g.: 8.12, 9.42, 12.24; the same in Epictetus, e.g.: 1.27.7, 3.10.1, 3.18.1, and in Seneca (quotiens): Ep. 71.2. 
by Marcus Aurelius suggests that the text was not intended to be a treatise but a series of notes which could have assisted him during his philosophical and moral progress. There was no disharmony between Marcus as a philosopher and the social functions and commitment he was obliged to fulfil. He practiced philosophy as an emperor, a judge and a soldier. His interactions with the world tested his philosophical attitude.

\section{CONCLUSIONS}

Medicine and rhetoric, which significantly influenced the evolution of ancient Greek and Roman philosophy, provided useful intellectual tools which enabled ancient philosophers to think about the human self from the perspective of its development. Medical analogy paved the way to speak about the therapy of the human soul, and rhetoric inspired how to use words persuasively as a means in this therapy. As Chaim Perelman has pointed out, the most essential part of ancient rhetoric is inventio, or reflection on types of argumentation and appropriate argumentative schemes (topoi). The therapeutic approach means that arguments are case-sensitive, goal-oriented, utterances have an illocutive force, and the therapeutic effectiveness prevails over doctrinal purity. This way of reasoning goes beyond the theoretical approach and finds its parallel in insistence on the utilitas of argumentation, which is typical of rhetoric. There are a variety of formal and argumentative strategies in Roman Stoicism which can be called therapeutical. Literary forms like diatribe, dialogue, selfdialogue, and such genres as consolation or protreptic go alongside schemes of argumentation and various rhetorical devices which enhance the persuasive effect. Each of the above-mentioned authors has a distinctive way of teaching and formulating thoughts, but at the same time they share a common bulk of opinions, premises and arguments, which allows readers to obtain a full picture of how ancient philosophy functioned as therapy of the soul and a way of life.

\section{BIBLIOGRAPHY}

Primary texts:

Epictetus. (1925-1928). The discourses as reported by Arrian, the manual, and fragments. (W.A. Oldfather, Trans.). Cambridge: Harvard University Press.

Epictetus. (2008). Discourses and selected writings. (R. Dobbin, Trans.). London: Penguin Classics.

Epicurus. (1994). Selected writings and testimonia. (B. Inwood \& L.P. Gerson, Trans.). Indianapolis: Hackett.

Lutz, C.E. (1947). Musonius Rufus, The Roman Socrates. Yale Classical Studies, 10, 3-147. 
Marcus Aurelius et al. (1919). The correspondence of Marcus Cornelius Fronto with Marcus Aurelius Antoninus, Lucius Verus, Antoninus Pius, and various friends. (C.R. Haines, Ed. \& Trans.). Cambridge: Harvard University Press.

Marcus Aurelius. (1979). Marcii Aurelii Antonini Ad se ipsum libri XII. (J. Dalfen, Ed.). Leipzig: Teubner.

Marcus Aurelius. (1994). The meditations of the emperor Marcus Antoninus. (A.S.L. Farquharson, Ed. \& Trans.). Oxford: Oxford University Press.

Musonius Rufus. (1905). C. Musonii Rufi Reliquiae. (O. Hense, Ed.). Leipzig: Teubner.

Seneca. (1900). L. Annae Senecae Opera quae supersunt. (C. Hosius, Ed.). Leipzig: Teubner.

Seneca. (1925). Ad Lucilium epistulae morales. (R.M. Gummere, Trans.). London \& New York: Heinemann.

Simplicius. (1966). Commentaire sur le Manuel d'Epictete. (I. Hadot, Ed.). Leiden: Brill.

Simplicius. (2002). On Epictetus Handbook 1-26. (Ch. Brittain \& T. Brennan, Trans.). London $\&$ New York: Duckworth.

Stoicorum veterum fragmenta. (1903-1924). (H. von Arnim, Ed.). Leipzig: Teubner.

Secondary texts:

Alexandre, M. (1979). Le travail de la sentence chez Marc-Aurèle: philosophie et rhétorique. La Licorne, 3, 125-158.

Annas, J.E. (2000). Philosophical therapy, ancient and modern (pp. 109-128). In: M.G. Kuczewski \& R. Polansky (Eds.). Bioethics. Ancient themes in contemporary issues. Cambridge: MIT.

Banicki, K. (2015). Therapeutic arguments, spiritual exercises, or the care of the self: Marta Nussbaum, Pierre Hadot and Michel Foucalt on ancient philosophy. Ethical Perspectives, 22, 601-634.

Brunt, P.A. (1974). Marcus Aurelius in his Meditations. Journal of Roman Studies, 64, 1-20.

Calboli Montefusco, L. (1996). Quintilian and the function of the oratorical exercitatio. Latomus, 55, 615-625.

Calboli, G. (1990). From Aristotelian lexis to elocutio. Rhetorica: A Journal of the History of Rhetoric, 16, 47-80.

Champlin, E. (1974). The chronology of Fronto. The Journal of Roman Studies, 64, 136-159.

Cortassa, G. (1989). Il filosofo, i libri, la memoria: poeti e filosofi nei 'Pensieri' di Marco Aurelio. Torino: Tirrenia stampatori.

Dalfen, J. (1967). Formgeschichtliche Untersuchungen zu den 'Selbstbetrachtungen' Marc Aurels, München: Universitat München.

Giavatto, A. (2008). Interlocutore di se stesso. La dialettica di Marco Aurelio, Hildesheim: G. Olms Verlag.

Gill, Ch. (1985). Ancient psychotherapy. Journal of the History of Ideas, 46, 307-325.

Gross, A.G. \& Dearin, R.D. (2003). Chaim Perelman. Albany: State University of New York Press.

Hadot, I. (1969). Seneca und die griechisch-römische Tradition der Seelenleitung. Berlin: Walter de Gruyter.

Hadot, P. (1995). Philosophy as a way of life. Spiritual exercises from Socrates to Foucault. (M. Chase, Trans.). Oxford: Blackwell.

Hadot, P. (1998). The inner citadel. The Meditations of Marcus Aurelius. (M. Chase, Trans.). Cambridge \& London: Harvard University Press.

Jordan, M.D. (1986). Ancient philosophic protreptic and the problem of persuasive genres. Rhetorica: A Journal of the History of Rhetoric, 4, 309-333. 
Kasulke, Ch.T. (2005). Fronto, Marc Aurel und kein Konflikt zwischen Rhetorik und Pbilosopbie im 2. Jh. n. Chr. München \& Leipzig: K.G. Saur.

Lain Entralgo, P. (1970). The therapy of the word in classical antiquity. (L.J. Rather \& J.M. Sharp, Trans.). New Haven: Yale University Press.

Lausberg, H. (1998). Handbook of literary rbetoric. A foundation of literary study. (D.F. Orton \& R.D. Anderson, Trans.) Leiden, Boston \& Cologne: Brill.

Long, A.A. (2004). Epictetus: A Stoic and Socratic guide to life. Oxford: Clarendon Press.

Łapiński, K. (2018). Ananeou seauton. Rozmyślania Marka Aureliusza w kontekście grecko-rzymskiej praktyki filozoficznej. Warszawa: Wydział Filozofii i Socjologii Uniwersytetu Warszawskiego.

McCormick, S. (2014). Argument by comparison: An ancient typology. Rhetorica: A Journal of the History of Rhetoric, 32, 148-164.

Möller, M. (2004). Talis oratio - qualis vita. Zu Theorie und Praxis mimetischer Verfabren in der griechisch-römischen Literaturkritik. Heidelberg: Universitätsverlag Winter.

Nussbaum, M.C. (1994). The therapy of desire. Theory and practice in Hellenistic ethics. Princeton: Princeton University Press.

Perelman, Ch. (1982). The realm of rhetoric. (W. Kluback, Trans.). Notre Dame \& London: University of Notre Dame Press.

Pisini, M. (2012). Docere principem. Educazione e formazione del principe nelle Epistulae di Frontone a Marco Aurelio (pp. 131-145). In: M. Maritano, M. Sajovic (Eds.). Docere et discere. La figura del maestro nella formazione scolastica del mondo antico pagano e cristiano. Roma: LAS.

Rabbow, P. (1954). Seelenfübrung. Methodik der Exerzitien in der Antike. München: Kösel.

Romilly, J. de (1975). Magic and rbetoric in ancient Greece. Cambridge: Harvard University Press.

Rutherford, R.B. (1989). The 'Meditations' of Marcus Aurelius. A study. Oxford: Oxford University Press.

Schofield, M. (2007). Epictetus on Cynicism (pp. 71-86). In: A.S. Mason \& Th. Scaltas (Eds.). The philosophy of Epictetus. Oxford: Oxford University Press.

Sellars, J. (2009). The art of living. The Stoics on the nature and function of philosophy. London: Ashgate.

Stephens, W.O. (2007). Stoic etbics: Epictetus and happiness as freedom. London: Continuum.

Stróżyński, M. (2017). Rhetoric and spiritual exercises in Marcus Aurelius' Meditations. Eos, 104, 285-301.

Tieleman, T. (2003). Chrysippus' 'on affections'. Reconstruction and interpretation. Leiden: Brill.

Voelke, A.-J. (1993). La philosophie comme thérapie de l'âme: études de philosopbie hellénistique. Fribourg: Cerf.

Xenakis, J. (1969). Epictetus. philosopher-therapist. Hague: Martinus Nijhoff. 